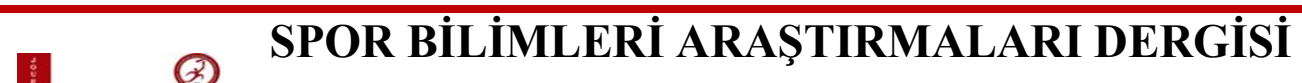

Journal of Sport Sciences Researches

http://dergipark.gov.tr/jssr

ISSN: 2548-0723

\title{
Padişah Cirit Bindi! \\ (Cirit Sporunu İcrâ Eden ve Destekleyen Osmanlı Sultanları)
}

\author{
Ahmet YÜKSEL ${ }^{1}$, Mehmet GÜL ${ }^{* 2}$, Okan GÜVEN ${ }^{3}$ \\ ${ }^{1}$ Cumhuriyet Üniversitesi, Edebiyat Fakültesi, Tarih Bölümü, ORCID iD: 0000-0001-5353-1989 \\ ${ }^{2}$ Cumhuriyet Üniversitesi, Beden Ë̆itimi ve Spor Yüksekokulu, ORCID iD:0000-0002-3080-5155 \\ ${ }^{3}$ Cumhuriyet Üniversitesi, Edebiyat Fakültesi, Tarih Bölümü, ORCID iD: 0000-0002-8589-1433
}

\section{$\ddot{O} \mathbf{z}$}

Atlı cirit, İslâmiyet öncesinde ve sonrasında Türklerce icra edilen önemli sporlardan birisidir. Geçmişinin bin yıllara dayanıyor olması münasebetiyle atlı cirit artık bugün geleneksel bir ata sporudur. Zaten uzak ve yakın mazisi savaşlarla dolu olan Türklerin yaşamında at çok müstesna bir yere ve değere sahip olmuştu. Bu münasebetle bir tür savaşa hazırlık niteliği de göstermesi atlı ciridi Türkler için daha özel kılmıştı. Bunun yanında atlı cirit ayrıca bir temaşanın, eğlencenin ve ihtişam gösterisinde bulunmanın temel öğelerinden birisi olmuştur. Bütün bu nitelikleri, oyunun neden yüzyıllarca Türkler tarafından icra edildiğini anlamımızı kolaylaştırmaktadır.

Selçuklular başta olmak üzere hemen bütün Türk devletlerinde atlı cirit sporu icra edilmiştir. Osmanlılar zamanına gelindiğinde ise sultanların da sıklıkla cirit oyun sahasında boy gösterdikleri görülmektedir. İşte bu çalışma özellikle atlı cirit sporunu bizzat icra eden yahut oyunun oynanması için gerekli zemini oluşturarak katkı sağlayan Osmanlı sultanları üzerine yoğunlaşmaktadır. Bu kapsamda hangi sultanların ne vakitler cirit oynamış yahut oynattırmış oldukları, oyunlara ve oyunculara ne tür bir destek sağladıkları gibi meseleler çalışma boyunca üzerinde durulan başlıca konular olmuştur. Bahsedilen meselelere dair mevcut literatürde bir hayli bilgi bulunmaktadır. Çalışmaya temel teşkil eden başlıca kaynak grubunu Osmanlı arşiv vesikaları ile kronikler oluşturmaktadır. Ayrıca konuya ilişkin olarak yapılmış araştırma-incelemelerden de istifade edilmiştir. Bu şekilde oluşturulan çalışmayla Osmanlı sultanları ve cirit arasındaki ilinti ortaya konulmuş, ayrıca Osmanlı sarayı ve çevresinde cirit müsabakalarının düzenlenmesine atfedilen geleneksel önem ve sağlanan destek hakkında önemli olduğu düşünülen bazı bilgilere ulaşılmıştır.
Orijinal Makale

$\underline{\text { Yayın Bilgisi }}$

Gönderi Tarihi: 24.01 .2018

Kabul Tarihi: 23.06.2018

Online Yayın Tarihi: 30.06 .2018

DOI: $10.25307 /$ jssr.383087

Anahtar kelimeler:

Cirit Sporu, Atlı Cirit, Osmanlilar,

Osmanlı Sultani.

\footnotetext{
* Sorumlu yazar: Mehmet GÜL, E-mail: mgulsivas@gmail.com
} 


\title{
Sultan Plays Jereed! (Ottoman Sultans Who Plays and Supports the Jereed Sport)
}

\begin{abstract}
Djerid game one of the important sport were played by Turks before and after the period of Islam. Today mounted jereed is a traditional ancestor sport now because of its past date backs to thousand years. The horse had a very exceptional place and value in the life of the Turks who were fulfill their past and near history with wars. In this regard mounted jereed is more special for Turks by as a kind of quality for preparation of war. Besides, mounted jereed is also one of the basic item of a festival to show fun and splendor. All these qualities make it easier for us to understand why the game was played by Turks for centuries.

In all the Turkish states, especially the Seljuks, mounted jereed was performed. When it comes to the Ottomans, it is seen that the sultans also appeared frequently in the playground of jereed. This work is especially focused on the Ottoman sultans who played the game himself or contributing by creating a necessative ground for the sport. In this context the main topics are what time and which sultan were play or run the game and what kind of support they provide to the players or games have been discussed during the study.

There is considerable information in the current literature on the mentioned issues. The main source group that constitutes the basis for the study is Ottoman archive documents and chronicles. It has also benefited from the researchs and review studies on the subject. In this way, the relation between the Ottoman sultans and jereed was revealed and reached on some information which thought to be important about given traditional importance and support for the organization of the mounted jereed competitions where were did in and around the Ottoman palace.
\end{abstract}

Keywords:
Sport of Jereed,
Mounted Jereed, Ottomans,
Ottoman Sultan.

\section{GIRIŞ}

Atlı cirit sporuna dair ortaya konulan bilgi ve çalışmalar Cumhuriyet Devri tarihçiliği için çok yenidir. Bu bölüm “Atlı ciritin” Osmanlı dönemindeki oynanma şekli, amacı ve içeriğini yansıtan çalışmalar çok sınırlıdır. Bu alandaki belli başlı çalışmalar: Ata Sporu Cirit, 1974; Çiftçi, 2011; Dingeç, 2011; Gezder, 1998; Halıcı, 1993 olarak karşımıza çıkmaktadır. Bunun içindir ki kimi zaman bu sporun nasıl oynandığı, sporun hazırlık ve oynanış esnasındaki unsurlarının neler olduğu dahi üzerinde ihtilaf yaşanan ve bilinmezlikleri olan meseleler arasında bulunmaktadır. Bu münasebetle gayet dar ve spesifik olan "Cirit Oynayan Padişahlar" konusuna geçmeden evvel cirit hakkında açıklanmayı bekler bazı temel yapıtaşları mevcuttur. Evvela cirit sporunun oynanışıyla ilgili malzemelerin/unsurların neler olduğunun bilinmesi, sonrasında bu unsurlarla atlı ciridin nasıl oynandığına açıklık getirilmesi gerekmektedir. Araştırmanın ana konusunun Osmanlı padişahları olması hasebiyle, Osmanlı ve cirit kavramlarının nasıl yan yana geldikleri, yani sporun Osmanlı'daki tarihsel arka planı da hâlihazırda en genel hatlarıyla aktarılması elzem olan hususlardandır. Zira bu temel yapıtaşlarının açıklanması meselesi, cirit oynayan Sultan portresini resmedebilmek adına çalışma içerisinde kendisine yer bulması gereken öğelerden biri haline gelmiştir. Ancak tüm bunları yaparken çalışmanın ana akışını bozmamak ve bir bildiri metninin özüne sadık kalabilmek adına çok fazla ayrıntıya yer vermekten özellikle kaçınıldığını da peşinen belirtilmekte fayda vardır.

İnsanın bu sporu yapabilmesi adına gereksinim duyacağı ilk nesne "cirit"dir. Etimolojik açıdan Arapça kökenli olan ve "hurma ăgacının soyulmuş dalı" (Halıc1, 1993) anlamına gelen "cirit”e "sopa" da denilmektedir (Sümer, 1983). Ciritbâz olarak da isimlendirilen sporcunun kullandığ1 ciridin çapı ortalama $5 \mathrm{~cm}$, uzunluğu ise $110 \mathrm{~cm}$ civarındadır. Cirit, kullanıcısının tarz ve arzusu ekseninde farklı görsel malzemeyle donatılma özgürlük ve ayrıcalığına da sahiptir. Bu özgürlük, boyanarak işlenmiş cirit üzerindeki motiflerle kendisini görücüye çıkarır. 
Anadolu-Türk menşeli olduğu da iddia edilen (Çiftçi, 2011) cirit sporunun icra edilebilmesi noktasında gerekli olan bir diğer önemli öğe ise "elbette" sahadır. Bazen onlar bazense yüzler basamağındaki sayılarla ifade edilen kalabalık bir toplulukla oynandığından cirit sahası alabildiğine büyük olmalıdır (Güven, 1999). Atların koşu mesafesi ve hızları düşünüldüğünde hem görsel zenginlik hem de seyirci güvenliği açısından sahanın büyüklüğü bir gereklilik halini almaktadır. Bugün profesyonel (her yıl Atlı Cirit Türkiye Şampiyonasına katılım sağlama) olarak icra edilen atlı cirit oyunu için özel olarak oluşturulmuş sahalarda söz konusu hususiyetleri görebilmek mümkündür. Buna karşın kuralsız şekilde oynanan atlı cirit sporu için mahsulü toplanmış veya hiç ekilmemiş boş arazilerin kullanıldığı da bilinmektedir.

Adından da anlaşılacağı üzere cirit sporunun olmazsa olmaz diğer bir öğesi “at"tır. Tek heceli ve öz Türkçe bir kelime olan at (Baykara, 2009b) "binme, yük çekme, yarış, spor veya taşıma gibi hizmetlerde kullanılan tek tırnakl ve omurgalı bir hayvandır" (Çınar, 1995). At, Türkler için en başta bir ulaşım vasıtası olarak kullanılmıştır (Baykara, 2005). Sonrasında ise gerek savaş alanındaki kullanımıyla gerekse etinden, sütünden ve derisinden istifade edilmesiyle Türklerin hem hayatını kolaylaştıran hem de bu hayatın devamlılı̆ıını sağlayan bir öğeye dönüşmüştür (Baykara, 2005; Emiroğlu ve Yüksel, 2009; Gülensoy, 2011; Kafesoğlu, 2010; Ögel, 1985; Sümer, 1983). Ancak atın en büyük potansiyele sahip olduğu kullanım alanı olan ordudan 1960'lı yıllarda çıkarılmış olması, onun ilerleyen zaman içerisinde Türkiye'de gözden uzaklaşmasına ve nihayet düşmesine, haliyle eski önemini yitirmesine zemin hazırlamıştır (Baykara, 2009a).

Cirit atına gelinecek olursa genel eğilim ciritbâzın kendi atını kendisinin seçmesi şeklindedir. Öte yandan atın da binicisini seçme hakkının bulunduğunu söylemek mübalağa olmayacaktır. Çünkü atların kendilerine hükmetmek isteyen yabancı binicilere pek sıcak bakmadıkları ve bunu da onlara hissettirmekten çekinmedikleri bilinmektedir.

Ciritbâz tarafından cirit atında aranan temel özellikler ise atın boyun kırma talimlerinin iyi yapılmış olması, manevra kabiliyeti ve zamanla müziğe alışmış olmasıdır. Müziğe alışan cirit atının ritimle içinin kıpırdaması ve oyun esnasında heyecan ve isteğini kaybetmemesi gerekir. Boyun kırma işlemlerinin iyi yapılması atın manevra kabiliyetini etkileyen bir özelliktir ki dörtnala giderken ciridin atılması sonrasında atın aniden manevra yaparak geriye doğru dönmesi ve tekrar dörtnala koşması gerekebilir. Ancak cirit atlarının çoğunluğunun ıskartaya çıkan yarış atları olması nedeniyle istenilen bu özelliklerin tamamı bir atta bulunmamakta veya olgunluğa erişene kadar eğitilmediklerinden dolayı atların bazı özellikleri istenilen düzeylere ulaşamamaktadır. Ayrıca atın sağrı yüksekliği gibi tamamen ciritbâzın şahsî tercihlerine bağlı özellikler taşıması da gerekmektedir. Son olarak atlı cirit sporunun uygulayıcısı olan insan faktöründen de bahsetmek gerekirse, esasında yukarıda sıralanan vasitaların tamamlanmasından sonra oyunculara sadece aralarında organize olmak ve oyuna başlamak kaliyor. 


\section{Atlı Cirit Nasıl Oynanır?}

Atlı cirit oyunu kendi içerisinde ikiye ayrılmaktadır. Birincisi, belli kurallarla resmî turnuvalar ve müsabakalar dâhilindeki oyuna "Kurallı Cirit" denir. İkincisi ise "Kara Cirit" şeklinde tanımlanan bir diğeri ise belli normları olmasına rağmen kesin kurallar barındırmaz ve genellikle dügün ve bayram gibi merasimlerde halkça oynanır. Burada ilk olarak ciritlerini ellerine alıp, atlarına binen sporcular (veya dügünde kız tarafı ile erkek tarafı) iki ayrı takım içerisinde organize olarak sahadaki yerlerini alırlar. Oyuna başlayacak olan takımdan bir ciritbâz atıyla hareketlenerek karşı takıma doğru gider ve ciridini firlatır. Kendisine cirit firlatılan oyuncu, bazen tek başına bazen de birkaç takım arkadaşıyla birlikte ciridi firlatan atlıyı takip etmeye başlar. Amaç, ciridi fırlatanın kendi takımına varmadan, ciridin firlatıldığı oyuncu tarafindan ciritle vurulması veya yakalanarak bağışlanmasıdır. Şayet bu eylemler gerçekleşmezse bu kez takipçi kendisine yapıldığı gibi ciridini karşı takımdan birine firlattıktan sonra kaçmaya başlar. Oyun bu şekilde taraflar yenişene veya belirlenen süre dolana kadar devam edip gider. Oynanış tarzı ana hatlarıyla yukarda anlatıldığı gibi olan kara cirit Osmanlıların Balkanlar istikametinde girişilen seferleri sırasında Edirne'de, Anadolu tarafindaki askerî hareketliliklerde ise Sivas ve Konya gibi menzil durak noktalarında askerlerce icra edilirdi (Kahraman, 1995). Bugün de bazı Anadolu vilayetlerinde, özellikle de köylerde bayram ve düğün merasimleriyle Cuma veya Bayram namazlarından sonra oynanmaktadır (Bozkurt, 2010).

Kara cirit her ne kadar daha heyecanlı ve hareketli geçse de bu oyunu daha anlaşılabilir ve kavranabilir kılan resmî müsabakalar kapsamında oynanan kurallı cirittir. Mesela resmî müsabakalarda rakip oyuncunun ciridi fırlatmasından sonra onu karşı takımdan sadece bir oyuncu takip edebilir. Oysa yukarıda da dikkat çekildiği üzere kara cirit de böyle bir durum söz konusu değildir. Ciridi ilk fırlatan sporcuyu karşı takıma mensup birden fazla oyuncu takip edebilmektedir. Ayrıca resmî müsabakaları daha heyecanlı kılan ciritbâzın eyer boşaltma gibi maharetler göstermesi, rakibini ciritlemesi veya bağışlaması ve bütün bunların da puanlamaya tabi tutulması gibi unsurlardır (Güven, 1999).

\section{Türklerde Atlı Sporlar veya "Tarihsel Arka Plan"}

Türk hükümdarları birçok atlı sporla meşgul olmuşlardır. Bunların başında "avcılık" gelmektedir. Aralarında Osmanlı padişahları da olmak üzere, Türk hükümdarlarının avcılığa karşı her zaman özel bir ilgileri söz konusu olmuştur. Bir örnek olmak üzere, Büyük Selçuklu Sultanı Melikşah'ın (1072-1092) ${ }^{\dagger}$ avcılıkta gayet mahir olduğu bilinmektedir (Güven, 1999). Ayrıca hem Osmanlılar öncesinde hem de Osmanlılar zamanında hükümdarların sadece av mevsimlerine mahsus olarak tutulmuş "Hünernâme" gibi nice özel kroniğin varlığ konuya atfedilen önemi göstermektedir. On dokuzuncu Osmanlı padişahı IV. Mehmed'in (1648-1687) "avcı" lakabını taşıyor olması ise bir rastlantı değildir (Özcan, 2003a). Kanunî Sultan Süleyman'ın (1520-1566) Budin'in fethi haberini bir av partisi dönüşünde almış olması da dikkat çekici bir gelişmedir. Onun avda ne kadar usta olduğunun en canlı tanığı ise

\footnotetext{
${ }^{\dagger}$ Burada ve sonrasında o sultanın adının geçtiği ilk yerde olmak suretiyle, isimlerin hemen yanında yer alan tarihler hüküm sürdükleri seneleri (miladî) işaret etmektedir.
} 
Hünername'de "tek okla üç yabandomuzu vurduğu" yönünde kendisine yer bulan ibaredir (Uslu, 2011).

Türk hükümdarlarınca yapılan ve bugün İngilizlerin "Polo"su olarak bilinen bir diğer spor ise çevgan'dır (Yıldız, 2002: 54). Çevgan'ı oynayan Türk hükümdarları için Memlûk Sultanı Baybars (1260-1277), Gazneli Mahmud (998-1030) (Güven, 1999: 217), Sultan Alp Arslan (1064-1072) ve Sultan Alâeddin Keykûbâd (1221-1237) (Yıldız, 2002: 31) örnek olarak gösterilebilir. Ancak çevganın cirit kadar tehlikeli bir spor olduğu unutulmamalıdır. Nitekim Hindistan'daki Türk kumandanlarından birisi olan Aybeg'in 1210 senesinde bu sporu yaparken hayatını kaybettiği tarihi kayıtlarla sabittir (Merçil, 2011). Sultan Melikşâh'ın aynı zamanda bir çevgan tutkunu olduğunu unutmadan belirtmek gerekiyor (Yıldız, 2002).

Esas konumuza gelinecek olursa, araştırmacılarca atlı cirit sporunun Türkler tarafından icra edilmesinin başlangıcıyla ilgili olarak birbirinden farklı tarihler verildiği görülmektedir. Ancak ortak söylem bu sporun Hunlar zamanından beri bilindiği ve oynandığı yönündedir. Oluşumunun temelinde ise atll-göçebe kültürü yatmaktadır. "İhtimal ki, o dönemde var olan okun yerini cirit; yayın yerini de el almıştır. Değişmeyen yalnızca attır. Zaman ve mekâna göre değişen şartlar, atl-göçebe dönemdeki savaşların seyirlik oyun haline gelmesinde etkili olmuştur. Bu dönemde Türklerin sürekli hazır olmak gayesi ile savaş eğitimlerini cirit oynayarak yaptıkları düşünülmektedir." (Çınar, 1995).

Bu oyunun (cirit) en iyi ve başarılı oyuncuları olarak Türkler gösterilmektedir. Hükümdarlardan başlanılacak olursa atlı cirit sporunu icra eden seçkin simalarla karşılaşılacaktır. Gazneli Mahmud'un ve Sultan Alp Arslan'ın tam bir cirit tutkunu olduğu bilinmektedir. Memlûk Sultanı Baybars, Meydan-1 Esved'de (Kara Meydan) ve Şam'da Gökmeydan'da yüzüne peçe takarak herhangi bir sporcu gibi mücadele etmiştir (Yıldız, 2002). Peçenin varlık sebebi Sultanın diğer oyuncularca tanınmamayı, o sayede kendisine iltimas geçilmeyip herkesin gerçek gücünü sahaya yansıtmasını istemesinden kaynaklanır.

Anadolu Selçuklularına ikbâl devrini yaşatan Sultan Alâeddin Keykûbâd, kış mevsimi geldiğinde kışlık sarayı olan Alâiyye'de imar işlerinden artakalan zamanlarında cirit müsabakaları düzenlettirir, kendisi de oyunlara bizzat ve sıklıkla iştirak ederdi (Yıldız, 2002). Cirit, sadece devlet ileri gelenlerince değil, cinsiyet ayrımı söz konusu olmaksızın toplumun hemen her kesimi tarafından yaygın bir şekilde oynanmıştır (Öngel, 2001). Öyle ki bugün bile Uşak'ta kadınların bu sporla hemhal oldukları bilinmektedir (Gülensoy, 2011: 194). Zaten Türklerin ilk zamanlarından itibaren yerleştikleri yerlere "at pazarı, atlık" gibi adlar vermeleri (Baykara, 2009c; Baykara, 2009b) onların at ve at sporları ile ne kadar iç içe olduklarının en açık göstergelerinden birisidir. Benzer bir göstergeyi Evliya Çelebi'nin meşhur seyahatnamesinde de bulmak mümkündür. Zira o, İstanbul esnafını dükkân dükkân sayarken "at değirmencilerinden at tellallarına, nal mıhçılarından ot ambarcılarına" kadar toplam 2412 dükkân ismi ile 14.630 çalışandan bahsediyor (Emiroğlu ve Yüksel, 2009). Bu da o dönemin yegâne ulaşım vasıtasının ve ordunun ana binitinin at olmasının da muhakkak tesiriyle sektörün o döneme göre ne kadar gelişmiş olduğuna işaret etmektedir. 
Peki, Osmanlılar ve diğer Türk devletlerinin hükümdarları neden cirit oynama lüzumu hissettiler? Her şeyden evvel, cirit oyunu beceri ve çeviklik kazandırır, ciritbâzlara yiğitlik ve kahramanlık aşılar. Ayrıca savaş öncesi yapılan bir idman olma özelliği gösterir. Bu idman sadece askerlerle sınırlı kalmaz. Yerel mahallerdeki gençlerce de oynanır ve onların dikkat çekilen hususlarda pişmelerini sağlar. Dolayısıyla tarihinin önemli bir kısmı savaşlardan oluşan ve o münasebetle her zaman yetişmiş askere ihtiyaç duyan Osmanlılarda bahsedilen ihtiyacı karşılamanın önemli vasıtalarından birisi olarak görülmüş olabilir cirit. Dahası bu oyun sultanları halk ile kaynaştırmanın bir vasıtası, tadılan bir zaferin kutlanma biçimi de olmuştur. Öte yandan tecrübe edilen yenilgilerin acısını dindirmek için de cirit oynanmıştır (Yıldırım, İmamoğlu ve Türkmen, 2002). Kısacası cirit hem Sultan hem de halk için önemli bir motivasyon kaynağı olmuştur diyebiliriz.

\section{Devletlï Âlem-Penâh Sporcu Sultan: Cirid Binen Padişah}

Osmanlı sultanlarının neredeyse tamamının kendilerine ait atları ve o atlara mahsus özel ahırları vardı. Dolayısıyla atlar ve ahırlar "sultan ile atlı sporlar" arasındaki bağın en önemli göstergelerinden birisi olmuştur. Osmanlı sultanlarının hemen tamamının at bindiği ve biniciliği büyük maharet ve şevkle yaptıkları bilinmektedir. Aynı şekilde sultanların neredeyse tamamının bir şekilde cirit sporuyla ilgilendiklerini söylemek de yanlış olmayacaktır. Bu ilginin Osmanlı sultanları arasında iki farklı şekilde ortaya çıktığı görülmektedir. Birincisi cirit oynamasa dahi destek çıkarak o spora olan ilgisini esirgemeyen sultan profilidir. İkinci profil ise bizzat cirit binen Devletlü Âlem-Penâh Sporcu Sultan'a aittir.

Padişahların hemen tamamı cirit binsin veya binmesin kadim bir devlet geleneği halini almış olmasının da muhakkak tesiriyle cirit müsabakaları düzenlettirmişlerdi. Hatta gözdağı verme amacıyla İstanbul'daki yabancı devletler elçilerine özel cirit müsabakaları yapıldığı zamanlar da Osmanlı tarihinde yaşanmıştı. Elçi yahut misafirlere özel gösteri amaçlı yapılanların yanında sultanların kendi "seyr ü temaşâları" için cirit turnuvaları tertip ettirmeleri ise oldukça sıradan bir gelişmedir dersek mübalağa etmemiş oluruz. Aşağıda yeri geldiğince aktarılacak olan arşiv vesikaları 1şı̆̆ında sultanların da bizatihi o müsabakalara iştirak ettikleri görülmektedir (Yıldırım, İmamoğlu ve Türkmen, 2002). Zaten iştirak etmemeleri için görünürde hiçbir neden yoktur. Çünkü imparatorluğun başına geçmeden evvel geçirdikleri şehzadelik yıllarında cirit binmek gibi bazı sporların özel eğitimini alıyorlardı (Zorba, 2014).

Sultanların cirit sahasında bizzat boy göstermeleri şeklinde ortaya çıkan gelişme, bu çalışmanın başlğıını da şekillendiren "Padişah Ciride Bindi!" sözünün devlet erkânı (Yıldız, 2002) arasında bir klişeye dönüşmesine vesile olmuştu. Tespit edilebildiği kadarıyla, Orhan Gazi, I. Murad, I. Mehmed, II. Mehmed, II. Bayezid, III. Murad, III. Mehmed (Gezder, 1998), I. Ahmed, II. Osman, IV. Murad, IV. Mehmed, III. Ahmed, III. Mustafa (Karal, 1942), I. Mahmud (Özcan, 2003b) I. Abdülhamid, III. Selim, II. Mahmud (Güven, 1999), Abdülaziz (Küçük, 1988) ve nihayet II. Abdülhamid bizzat cirit sporu icra etmiş Osmanlı sultanları olarak karşımıza çıkmaktalar. Zaten ön planda II. Bayezid, II. Osman, II. Mustafa, III. Murad, III. Mustafa, Abdülaziz ve II. Abdülhamid olmak üzere Osmanlı padişahlarının hemen tamamının çok iyi at bindiklerini ve bundan ziyadesiyle keyif aldıklarını bir kez daha hatırlatmakta fayda vardır . Hanedana ismini veren Osman Gazi'nin (1299-1326) kaynaklara yansiyan fizikî 
tanımlamalarda "teşekkulât-ı bedeniyesinin tam ata binecek surette" olduğuna dikkat çekilmesi esasında Osmanoğulları'nın at binmeyi neden sevdiklerinin, at binmede ve atlı cirit oyunlarında nasıl mahir olduklarının genetiğe dayalı olarak açıklanabilme imkânının da bulunduğunu düşündürmektedir.

Orhan Gazi (1326-1362), Bursa'nın fethi sonrasında düzenlediği şenliklerin yapıldığı alanlardan birisini yarış ve cirit müsabakalarına tahsis etmişti (Ata Sporu Cirit, 1974). Ancak o tahsisat tek başına Sultan'ın cirit bindiğini ifade etmeye kâfi gelmiyor. Aynı şekilde Edirne fethedildikten sonra I. Murad'ın (1362-1389), programda cirit müsabakasının da yer aldığı bir şenlik düzenlettirdiği bilinmekteyse de o müsabakaya bizzat katılıp katılmadığına ilişkin kaynaklara yansıyan herhangi bir bilgi yoktur. I. Bayezid devrine (1389-1402) gelindiğindeyse ciride karşı hemen her tabakadan bir rağbetin artarak sürdüğü tespit edilmiştir (Halıc1, 1993).

Ciride bindiği kaynaklara açıkça yansıyan Osmanlı sultanıysa devletin ikinci kurucusu olarak tanımlanan I. Mehmed'tir (1412-1421). Nitekim onun Enderun'daki Ak ve Kara Ağalarla birlikte cirit oynadığı kaynaklara yansımıştır. Bu oyunlar esnasında Enderun ağaları Lahika (Lahanacılar) ve Yamyacı (Bamyacılar) adıyla kendi aralarında takımlar oluştururlardı. ${ }^{\star}$ Bizzat I. Mehmed tarafından kurulmuş ${ }^{\S}$ olan (Gezder, 1998) bu takımların alay sancakları ve giydikleri başlık, mintan ve şalvarların kendine has renkleri olurdu. I. Mehmed kimi zaman o takımlardan birisine dâhil olur ve bizzat cirit binerdi. Öyle zamanlarda karşı takımda oluşan oyuncu eksikliği veziriazam veya vezirlerden birinin katılımıyla giderilirdi (Yıldız, 2002).

Kimi zaman takımların birbirine karıştı̆ı ve meydanda yüzlerce insanın cirit oynadığı bu müsabakalara II. Osman'ın da (1618-1622) katılmış olduğu bilinmektedir. (Yıldız, 2002). İyi bir binici olan Genç Sultan'ın çok sevdiği ve sık sık gezintiye çıktı̆̆ı "Sisli Kır" adlı atı da bir cirit müsabakası esnasında ölmüştü (Emiroğlu ve Yüksel, 2009).

Kemankeş olan, cirit müsabakaları düzenleten ve bizzat ciride binen Osmanoğulları'ndan bir diğeri ise Sultan IV. Murad (1623-1640) olmuştu. Onun güçlü fiziki yapısı, sporcu kimliği ve cündilikteki (binicilik) mahareti konusunda kaynaklar ittifak halindedir. Öyle ki bir atını sürerken yanında boşta koşan bir başka atın eyerine atladığı rivayet edilir. Cirit savurmadaki mahareti ise varllğını, kaynakların müttefik olma durumunu koruduğu bir diğer niteliğine, Sultan'ın "bazu" kuvvetine borçludur (Mehmet Halife, 1976; Danişmend, 1972; Lamartine, 2008; Akgündüz-Öztürk, 1999). Yaya/menzil ciridi firlatmak da IV. Murad'ın en sevdiği ve sıklıkla yaptı̆̆ı sporlardan bir diğeri olmuştur. Hatta attığı ciritlerden birisi Topkapı Sarayı'ndan çıkarak II. Bayezid camiinin minaresinin dibine düşmüştür (Güven, 1999).

\footnotetext{
$¥$ Bu kimselerin nasıl cirit oynadıkları ile ilgili bkz. Hafız Hızır İlyas Ağa, 1987: 37, 59-61, 116, 117, 290

$\S$ Bu takımların kuruluşuna ilişkin farklı görüşler vardır. Bir rivayete göre savaş esnasında kimin daha çok asker öldürdüğüne dair Manisalı ve Merzifonlu askerler arasında bir kavga çıkmıștır. Kavga Genç Sultan'a aksedince o da kendince bir çözüm üretmiş, askerleri bir cirit müsabakasında karşı karşıya getirip aralarındaki soğukluğu gidermek istemiştir. Bu doğrultuda Merzifonlu askerleri Lahanacı, Manisalı askerleri ise Bamyacı olarak adlandırmıştır. Bu adlandırmaya ilham verense Merzifon'un lahanasının, Manisa'nın ise bamyasının sahip olduğu şöhrettir. Bundan sonra Sultan Mehmed Lahanacılar, Manisa'daki şehzadesi Murad (II) (1421-1451) ise Bamyacılar tarafına geçer ve oyun o şekilde icra edilir. (Dingeç, 2011: 79). İşte böyle bir maziye sahip olduğu bilinen isimler daha sonra Enderun ağalarınca da tercih edilmiştir. Bu ağalar, Topkapı Sarayı'nın kullanılmadığı yıllarda dahi Gülhane Parkı ile diğer bazı mahallerde cirit oynamışlardır (Yıldız, 2002: 80). Bir diğer iddia ise bahsedilen takımların II. Bayezid (1481-1512) tarafından kurulduğu yönündedir (Baykara, 2009b: 240).
} 
IV. Murad, seferler sırasında oluşturulan ordugâhlarda askerlerine cirit oynattığı (Topçular Kâtibi Abdülkâdîr Efendi, 2003) gibi bazen otağ-1 hümayunu da "cirit meydanına" kurdurtmuştu (Katip Çelebi, 2016). Evliya Çelebi, IV. Murad ve cirit arasındaki ilintinin canlı tanıklarından birisi olarak meşhur seyahatnamesinde konuya ilişkin önemli bilgiler aktarmaktadır. Mesela, Uyvar Kalesi altında yapılan (Evliyâ Çelebi, 2003) bir cirit oyununda boy gösteren, ancak bu gösterimin bedelini dört dişini birden kaybederek ödeyen seyyahımız eserinde Sultan Murad'ın yayan ciritle bir Arnavud kalkanını nasıl deldiğini büyük bir iştahla naklediyor (Akın Zorba, 2014). Aynı iştah, Avusturya imparatorunun elçisi kanalıyla hediye olarak gönderdiği kalkanları IV. Murad'ın ciritle delip geldiği yere iade etmesine ilişkin anlatıda da karşımıza çıkıyor (Evliya Çelebi, 1996). Sultanın dışa dönük güç denemeleri Türklerin penceresinden göze ve kulağa hoş gelse de içerde gerçekleştirilen benzer denemeler bazen beraberinde hüzün ve yas getirebiliyordu. 1635 Revan Seferi esnasında yaşanan bir hadise herhalde anlatılmak isteneni ortaya koymaya yetecek türdendir. Çünkü IV. Murad, atlı cirit oynarken ciritlediği (vurduğu) bir sipahiyi ölümcül şekilde yaralamıştı. (Naima Mustafa Efendi, 1968; Zinkeisen, 2011). IV. Murad'ın orantısız güç kullanımından hissesine düşeni alan, yani sadece Sultan'ın ciridini yemekle kalmayıp vücudunda derin hasarlar oluşan bir diğer isimse meşhur paşası Gürcü Mehmed'dir. Bu örneklerden sonra devrin canlı tanıklarından Hasan Beyzâde'nin (2004) "Sultan'ın ciridini isabet ettirdiği her şahsı atından düşürdügü̆" şeklindeki tespitinin kuru bir lakırdıdan yahut mübalağadan ibaret olmadığı anlaşılıyor. Aynı şekilde sultanların cirit müsabakaları için her zaman hazırda dokuz at bekletmeleri geleneğini IV. Murad'ın at sayısını kırka çıkararak (Yıldırım, İmamoğlu ve Türkmen, 2002) neden deldiğini açıklamak da kolaylaşıyor.

Kanuni'den sonra Osmanlı tahtında en çok oturan ve lakabının "avcı" olduğuna yukarıda değinilen IV. Mehmed'in (1648-1687) cirit sporunu en fazla icra eden sultanlar arasında kendisine üst sıralarda yer buluyor olması doğal karşılanmalıdır. İddiaya göre, IV. Mehmed 1665 yılı Aralık ayındaki bir sürek avının ardından Karadeniz kıyısındaki Uskumru Köyü'nde cirit binmişti. Kendisi oyuna dâhil olunca Sadrazamı da müsabakaya katılmış, ancak Sultan'ın firlattı̆̆ cirit yüzüne isabet edince Sadrazamın gözü morarmıştı (Yıldız, 2002). Öte yandan farklı kaynaklarla takip edildiğinde bu bilgilerde bazı ihtilaf ve çelişkiler tespit edilmektedir. Mesela ilgili çalışmada cirit oynayan sultanın adı IV. Mehmed yerine IV. Murad olarak, oyun mekânının ismi ise Uskumrı Çayırı yerine Uskumru Köyü şeklinde kaydedilmiştir. Bahsedilen tarihte ise Sadrazam Fazıl Ahmed Paşa'nın cirit oynamak yerine Habsburg seferiyle meşgul olduğu (Kolçak, 2012) bilinmektedir. Dolayısıyla Sultan'ın ciritlediği ve gözünde hasara yol açtı̆̆ paşanın İstanbul'daki Kapudan Mustafa Paşa olması dikkate haizdir (Abdurrahman Abdî Paşa, 2008: 215; Güven, 1999: 230). Ayrıca sultanın verdiği hediyelerle ciritlediği paşanın gönlünü aldığı iddia edilmişken olay hakkında bilgi veren yegâne kaynak durumundaki Abdurrahman Abdî Paşa Vekayinamesi’nde (2008: 215) "göz morartacak" düzeyde bir darp mevzundan bahsedilmez. Öte yandan IV. Mehmed'in Abdurrahman Abdi Paşa'yı söz konusu cirit hadiselerinin de yer aldığı eserini tamamlayıp takdim etmekte gösterdiği gevşeklik ve gecikmeden ötürü hazırda tuttuğu ciridiyle değneklemiş ve "git bunu da tarihine yaz!" demiş olması (Derin, 2008: 190) onun zamanında yaşanan cirit temalı ilginç hadiseler arasındadır.

Atlı cirit sporunu severek icra ettiğinden bahsedilen (Cezar, 1959; İlgürel, 1989) I. Ahmed (1603-1617) de meşhur vezirlerinden Nasuh Paşa ile birlikte cirit oynayarak "cirit ve padişah" 
konusuna zenginlik kazandıran sultanlar arasında yer almaktadır. Kaynaklara yansıdığı üzere 1612 senesinde Edirne'de bir cirit müsabakasını seyr ü temâşâ eden Sultan, içindeki cirit ateşine yenik düşen Nasuh Paşa'nın oyuna katılma isteğini geri çevirmez. Ardından onun ciritte ortaya koyduğu şevkle iştahı kabaran Sultan Ahmed "Zerrîn-i Şevket" adlı atına atladığı gibi kendisini birdenbire oyunun ortasında bulur. Böylece Sultan ve Vezir oyun içerisinde karşı karşıya gelmiş olurlar. Oyun esnasında firsatını bulmuşken Nasuh Paşa'nın sultanına ciridini savurma cesareti göstermemesine yahut savurmama nezaketinde bulunmasına karşın Sultan Ahmed eline geçen ilk firsatta ve herhangi bir tereddüt göstermeden paşasını değneklemiştir. Bunun üzerine Nasuh Paşa hemen durdurduğu atından inip soluğu Sultan'ın yanında almış ve yer öpmüştür. Bu davranışı ise ona Sultan'ın ödül kapısını açmıştır. (Topçular Kâtibi Abdülkâdîr Efendi, 2003).

Kronolojik takibe devam edilecek olursa cirit atmadaki maharetiyle nam salan padişahlar listesinde sıra yahut sahne Sultan II. Mustafa' ya (1695-1703) (Özcan, 2006), onun ardındansa III. Selim'e (1789-1808) ait. Bu sonuncusunun ciritle ilişkisi şair Naşid İbrahim'in (ö.1791) dizelerinde kendisine şu şekilde yer bulmuştur:

"Cenâb-ı Hazret-i Sultan Selim Hân-ı melekhaslet,

Ciride bindi cem idüb mukarreblerden erkânn.

Biri birine gerçi hamleler çok ittiler amma,

Cenâb-ı Padişah-ı kahramâni itti cevlânı.

Ciridi her atışsta birinin darb itti duşundan,

Kemâl-i zor-l darbindan havaya oldu perrani.

Sürünce esb-i düldülfam-ı misrisin şecaatle,

Feleklerde melekler cümle cümle tahsin ittiler anı."

(Kahraman, 1995: 502).

III. Selim ayrıca yukarıda işaret edilen takımlardan Lahanacılar'a karşı özel bir sempati beslemiştir. Buna karşın II. Mahmud'un favori takımının Bamyacılar olduğu bilinmektedir (Dingeç, 2011). Hazır söz kendisinden açılmışken II. Mahmud'un (1808-1839) cirit oynayan sultanlar arasında müstesna bir yere sahip olduğunu söylemek yanlış olmayacaktır. Şair Vasıf'ın aşağıdaki dizelerine kulak verilecek olursa reformist Sultan çok iyi bir cündi ve cirit oyuncusudur (Yıldız, 2002).

\footnotetext{
"Niyze silküb at çıkardıkça alay-ı hasmına,

Her gören tahsin ider ol Şah-ı ejdersavleti.

At kopardikça alaydan ayrllip ol yekketâz

Kal'a olsa fethider hasma hücum ü savleti."
}

(Kahraman, 1995: 502-503).

İlginçtir ki oynamayı o kadar sevmesine ve yukarıdaki mısralara hayat verecek kadar maharet göstermiş olmasına rağmen cirit oyunu II. Mahmud'un emriyle yasaklanmıştır. Sultanı böyle bir karar almaya iten sebeplere dair bir hayli iddia ortaya atılmıştır. Mesela yasağın Yeniçeri 
Ocağı'nın kapatılmasının hemen ardından (Baykara, 2009b) uygulama sahasına aktarılmış olması, olayın (aşağıda dikkat çekileceği üzere sıklıkla cirit oynadıkları bilinen) Yeniçerilerle ilişkilendirilmesine ve onlara duyulan nefretin bir yansıması şeklinde değerlendirilmesine kapı açmıştır. Yasağın diğer sebepleri ise daha ziyade Batı istikametinde girişilen reformlar etrafında kümelenir. Sözgelimi imparatorluğun bir reformlar çemberinden geçtiği günlerde Avrupalıların o tarz tehlikeli sporlara iyi gözle bakmamaları II. Mahmud'u öyle bir karar almaya itmiştir. Aynı yaklaşımın bir tezahürü olarak yasak; modernleşerek konvansiyonel bir şekle bürünmüş olan Osmanlı ordusunda kılıç-kalkan çağının çoktan kapanmış olması hasebiyle cirit sporunun mantığını yahut savaşlara hazırlık felsefesini yitirmiş olabileceği şeklinde de yorumlanmıştır.

Yasağa ilişkin iddia ve yorumlar yukarıda aktarılanlarla sınırlı kalmıyor. İlgili çalı̧malarda meseleye dair daha dikkat çekici olan iddialara tesadüf ediliyor. Mesela çok sevdiği Enderun ağalarından birisinin Lahanacılar ve Bamyacılar arasındaki bir cirit müsabakasında aldığı ağır yaralar nedeniyle ölümü II. Mahmud'u ciridi firlatan oyuncuyu cezalandırdıktan sonra oyunu da bütün imparatorluk zemininde yasaklama kararı almaya itmiştir. Ancak I. Selim, I. Ahmed, I. Abdülhamid ve III. Selim dönemlerinde benzer yaralanma vakalarının yaşanmış olmasına rağmen (Güven, 1999) bu oyundan hemen vazgeçmek gibi bir eğilimin söz konusu olmadığını hemen belirtmek icap ediyor. Farklı bir diğer iddiada ise yasağın perde arkasındaki isim olarak padişahın validesi Nakşidil Sultan'a işaret edilmektedir. Buna göre Valide Sultan, oğlunun ülkenin velinimeti ve aynı zamanda hayattaki tek Osmanoğlu (cemaatbaşı) olmasından mütevellit devletin bekası adına başına bir zeval gelmemesi için cirit sporunu yasak ettirmiştir.

İddia ve değerlendirmeler bir yana hem o günlerde hem de sonrasında imparatorluğun dört bir yanından cirit seslerinin işitilmiş olması II. Mahmud'un yasağının Anadolu'yu çok da bağlamadığını ve uzun süre devam etmediğini göstermektedir. Zira ciridi yasak eden Sultan'ın tahtında oturuyor olduğu 1838 senesinde Malatya'da cirit oynandığı Osmanlı ordusunu modernleştirmekle görevli Alman subaylarından Helmuth Von Moltke'nin (1800-1891) anılarında kayıtlıdır (Gezder, 1998: 94-95). II. Abdülhamid devrinde ve bizzat onun gösterdiği özel ilginin gölgesinde Söğüt’te Ertuğrul Gazi ve 24 Oğuz Boyu adına organize edilen şenliklerde de cirit müsabakalarının düzenlendiği bilinmektedir (Emiroğlu ve Yüksel, 2009).

Konuyu bitirmeden evvel "sultanlar ve cirit” temasına katk1 sağlayacağ düşünüldüğünden ünlü sadrazam, vezir ve beylerbeylerin de bazen bizzat cirit oynadıklarını bazen de oynattırdıklarını hatırlatmakta fayda vardır. Mesela Gelibolulu Mustafa Âlî (2003: 33), Kanunî Sultan Süleyman'ın makbul paşası Pargalı İbrahim'in At Meydanı'nda (sarayında) düzenlettirdiği cirit müsabakalarını izlediğini kaydetmiştir. Karlofça Antlaşması'nın mimarlarından Rami Mehmed Paşa'nın da (Ahıskalı, 2007) bir cirit tutkunu olduğu ve seyirci olarak bulunduğu müsabakalar sırasında vurulan ciritbazları gördükçe canının acıdı̆̆ (Anonim Osmanlı Tarihi, 2000). Cirit icra eden ricale bir örnek vermek gerekirse en çarpıcı model olarak karşımıza 1656-1661 yılları arasında Bosna Beylerbeyliği yapmış olan eskinin Kaptan-1 Deryası Seydî Ahmed Paşa çıkıyor (Öz, 2002). Kendisi Osmanlı tarihinin şöhret sahibi ciritbazlarından birisidir. Onu cirit ekseninde çarpıcı ve özel kılansa henüz paşa olmadığı günlerde cirit yüzünden Sultan İbrahim tarafından katli için verilmiş fermandır (Evliya Çelebi, 1999a). 
Cirit oyunları bazen imparatorluk yöneticileri arasında bir gövde gösterisine de dönüşmüştür. Nitekim merkezi idareye karşı isyanıyla kendince bir şöhrete kavuşan Abaza Mehmed Paşa'nın (ö.1634) cündîleriyle Sadrazam cündileri arasında bir müsabaka tertip edilmişti (Emiroğlu ve Yüksel, 2009). Son olarak Osmanlı sultanları karşısında hünerlerini sergileyen ciritbâzların Sadrazam veya diğer ricalin kapısında bulunan cündilerden oldukları unutulmamalıdır.

\section{İnayetlü Efendim Hazretleri: Ciridi Destekleyen Sultan}

Osmanlı padişahları arasında ciride binmemiş olanlar bulunsa da neredeyse hemen hepsinin cirit müsabakaları düzenlettirmiş, o müsabakaları keyifle seyreylemiş ve kısacası o sporun en önemli destekçisi oldukları noktasında kaynaklarda mutlak bir mutabakat vardır. Oyun başlamadan evvel sporcular padişahlarını selamlar, onun ve devletinin bekası için dua ederlerdi. Müsabakanın bitiminde padişah da oyunculara çeşitli ihsanlarda bulunurdu**. Oyun esnasında cirit yemekten kurtularak, eyer boşaltarak yahut ciridi havada yakalayarak maharetini ispat edenler için padişah daha özel ihsanlarda bulunurdu. Mesela IV. Mehmed, cündiliğini beğendiği bir ağayı 1659 senesinde Mısır Beylerbeyliği'ne tayin etmişti (Gezder, 1998: 51).

Padişahların özel gelir ve harcamalarının tutulduğu "ceyb-i hümayun" defterlerinin varlığı sayesinde oyunculara ne tür ihsanlarda bulunulduğuna ilişkin bir hayli bilgiye sahip olabilmek mümkündür. Mesela, II. Mustafa devrine ait bir "ceyb-i hümayun” defterinde kaydedildiği üzere 11 Haziran 1702 tarihinde Silahtar Ağa marifetiyle cirit uranlara yedişer altın bahşedilmiştir (BOA, TSMA.d. 2351, s.2, vrk.b,15 Muharrem 1114 / 11 Haziran 1702). Sultan I. Abdülhamid'in Binişli A $\breve{g} a$ Bağçesi'ne teşriflerinde cirit oynayan harem ağalarının keskinlerine zincirli veya beş altın ihsan edilmiştir. (BOA, TSMA.d. 2432, v.2b, 29 Zilhicce 1201 / 12 Ekim 1787; BOA, TSMA.d. 2434/116; 29 Rebiülahir 1203 / 27 Ocak 1789). Söz konusu defterler sayesinde acemi oğlanlarının da kendi aralarında cirit oynadıkları ve padişahın bahşişine müşerref oldukları bilgisine tesadüf edilmiştir. (BOA, TSMA.d. 2434/11, v.2b). Aynı şekilde III. Ahmed'in (1703-1730) teşrifleriyle İbrahim Paşa sarayında icra edilen cirit müsabakasında Cebecilere galebe çalan Yeniçeri Çorbacılarına bin kuruş ihsanda bulunulmuştur. Bu arada Cebeciler de unutulmamış ve onlara da 150 kuruş ihsan buyrulmuştur (BOA, TSMA.d. 2368, s.3, vrk.b). Dolayısıyla sadece galip gelenler için değil, yenilenler için de bahşiş kapısının, yani motivasyon kanallarının açık tutulduğu müşahede edilmektedir.

Sultanlar oldukça çetin ve haşin geçen cirit müsabakalarında ciddi yaralanmaların meydana gelmemesi için gerekli tedbirlerin alınması gerektiğini ilgililere her firsatta hatırlatırdı. Buna rağmen yukarıda yer yer temas edildiği üzere ne tedbir alınırsa alınsın cirit oyunları esnasında her zaman karşılaşılması muhtemel küçük yaralanmalardan başka daha ciddi ve kalıcı hasarlara yol açan büyük yaralanmalar sıklıkla yaşanılan durumlardı. Mesela II. Mustafa devrine ait bir “ceyb-i hümayun” defterinden anlaşıldığ 1 üzere, 1702 senesinde Alay Köşkü’nde oynanan cirit esnasında Hazineli Süleyman ve Kilerli Çukadar Hacı Ali yaralanmışlardı. Belki motivasyonlarını muhafaza etmeleri adına belki de yaralarını bir nebze olsun kapatmak için kendilerine beşer altın ihsan edilmişti (BOA, TSMA.d. 2351, vrk: b, 15 Muharrem 1114 / 11 Haziran 1702). Aynı yıl padişahın huzurunda oynanan cirit esnasında Cündî İbrahim adlı oyuncunun yüzüne urulmuş cirit nedeniyle ağzı yaralanmış, dişleri dökülmüştü. Bunun üzerine

\footnotetext{
** Padişah önünde oynanan ciridin ritüel ve normları için bkz. Güven,1999: 227-229.
} 
İbrahim'e beş altından başka Osmanlı sarayında çok kimseye nasip olmayan "saç ve sakal salma” ayrıcalı̆̆ı tanınmıştı (BOA, C.SM. 64/3222, 22 Ramazan 1113/ 20 Şubat 1702).

İhsan yahut ödüller sadece cirit oynayanlara özel değildi, bu sporun gerçekleştirilebilmesine katkı sağlayanlar için de lütuf kapısı ardına kadar açık tutulmuştu. Mesela arşiv kayıtlarına yansıdığı üzere, İznikmid kazasının kimi köylerinde yaşayıp ağaç işçiliğiyle meşgul olan bazı kimseler Sultan'in huzurunda oynanan cirit müsabakaları veya atlı cirit talimleri için ürettikleri cirit sopaları ( 8 bin değnek) mukabilinde tekâlif-i şâkka ve tekâlif-i örfîyye vergilerinden muaf tutulma gibi bir ödüllendirmeye mazhar olmuşlardı (BOA, C.SM. 49/2462, 23 Receb 1214 / 21 Aralık 1799).

Sağladığı temaşa zevki ve yarattığı heyecanın yanında Osmanlı padişahlarının cirit oyununa neden o kadar ihtimam gösterip müsabakaları desteklemiş olduklarının sebeplerine yukarıda temas edildiğinden onları burada ayrıca tekrar etmekten özellikle kaçınıldığını peşinen belirtmeliyiz. Sadece ayrıntı arz ettiği için padişahların Osmanlı topraklarına dâhil olan yabancı elçiler için düzenlettirmiş oldukları cirit oyunlarına ayrı bir parantez açmak gerekiyor. Görünürde elçileri onurlandırmak, esasında ise onlara imparatorluğun ihtişamını teşhir etmek gayesiyle düzenlenen ve harharî ciridi de denilen (Güven, 1999) bu "dehşet-engîz" oyuna tanıklık etmiş olan elçilerin en tanınmış simaları arasında Ogier Chiselin de Busbecq (16. yüzyıl), Dr. John Covel (17. yüzyıl) ve Rus elçisi Tolstoy (18. yüzyıl) bulunmaktadır (Yıldız, 2002). 1665 senesinde Osmanlı ülkesini ziyaret eden ve onuruna bir cirit müsabakası düzenlenmiş olan Habsburg elçisi Walter Leslie'nin ciridi kastederek "bu bir spor mu yoksa savaş mı?" yönünde şaşkınlıkla sarf edilmiş söylemi esasında Osmanlı merkez idaresinin cirit oyunu vasıtasıyla rakiplerine bir gözdağı verme şeklinde güttüğü gayeye nasıl ulaştığının en bariz ifadesi olmuştur (Kolçak, 2012). Vakanüvis Raşid Mehmed Efendi'nin (2013: s.1168) ismini zikretmediği bir başka Nemçe (Avusturya) elçisi de 3 Eylül 1719 tarihinde kendisi onuruna düzenlenen şenlikler kapsamında yer alan cirit müsabakasını seyretme, dolayısıyla Osmanlı ihtişamına çıplak gözle tanıklık edebilme ayrıcalığına sahip olmuştu. III. Ahmed'in kaleme alıp sadrazamına gönderdiği bir hatt-1 hümayununda o an itibariyle Kızlar ve Enderun ağaları arasında düzenlettirdiği cirit müsabakasını izlemekte olduğu bilgisine de bir parantez açmışt (BOA, AE.SAMD.III. 215/20805, 19 Rebiülevvel 1143/2 Ekim 1730).

Elçi kabullerinden başka şehzadeler için yapılan sünnet ile padişah kızları olan sultanlar için tertip edilen evlilik dügünleri kapsamında düzenlenen şenlikler sırasında da padişahlar cirit oynanmasını özellikle istemişlerdi. Mesela ciritbaz olduğuna yukarıda dikkat çekilen IV. Mehmed 1675 senesinde sünnet ve evlilik dügünleri münasebetiyle tertip ettirdiği 1675 Edirne şenliklerinde cirit oynatmıştı. (Hezarfen Hüseyin Efendi, 1998).

Düğünler gibi cülus ylldönümü yahut bayram benzeri özel günlerde Sultan'ın müsaadesi ve desteğiyle cirit oynanması ise Osmanlılarda adeta bir gelenek halini almıştı. Mesela Sadrazam Nevşehirli Damat İbrahim Paşa tarafından III. Ahmed'e takdim edilen bir telhiste (Osmanlı döneminde, sadrazamin, bir sorunu özet olarak yazı kendi düşüncesini de ekleyerek padişaha sunduğu kâğıtt) "kanun-ı kadîm üzere" bayramların ikinci ve üçüncü günlerinde oynanması adetten olan cirit için cündilerin Çubuklu Bahçe'de hazır bekletilmekte olduğu bilgisi aktarıldıktan sonra, Padişah'ın Şeyhülislam ve devlet ricali ile ne zaman teşrif edecekleri sorulmaktaydı. Padişahın 
cevab1 ise çoğu zaman olduğu gibi netti: “İnşallah'u-Te'âlâ yarın geliriz!” (BOA, AE.SAMD.III. 227/21846, 19 Rebiülevvel 1143 / 2 Ekim 1730). III. Selim'e takdim edilen bazı telhislerde de aynı duruma şahit olunmakta; ıyd-ı ahâd (Kurban Bayramı) veya ıyd-ı fitır (Ramazan Bayramı) dâhilinde "mut'âd-ı kadîm” olduğu üzere bayramın üçüncü gününde Saray-1 Âtîk-i Mâmure'de cirit oynanması hasebiyle Padişah oraya davet edilmekteydi. (BOA, Hatt-ı Hümâyûn, 1443/59277, 29 Zilhicce 1203 / 20 Eylül 1789; BOA, BOA, Hatt-l Hümâyûn, 188/8971, 1 Şevval 1211 / 30 Mart 1797; BOA, BOA, Hatt-ı Hümâyûn, 238/13239, 29 Zilhicce 1214 / 24 Mayıs 1800).

Bayramlarda Padişah huzurunda icra edilen cirit oyunu için yine bir gelenek (mut'âd) halini aldığı üzere, Osmanlı sarayından on iki adet "zinde" koyun ihsan edilmekteydi. III. Ahmed", I. Mahmud ${ }^{*}$, III. Mustafas ${ }^{\S \S}$, I. Abdülhamid ${ }^{* * *}$ ve III. Selim ${ }^{\dagger \dagger \dagger}$ devrine ait vesikalar sayesinde hem bu sultanların bayramlarda huzurlarında cirit oynatmış olduklarını bilmek hem de koyunların temin edilmesine ilişkin resmî prosedürün nasıl işlemiş olduğunu takip edebilmek mümkün olmuştur. Söz konusu vesikalara yansıdığ üzere Bostancıbaşı kaleme aldığı arzla adeta koyun ihsan edilmesi gerektiğinin hatırlatıcısı konumundaydı. Onun arzının ardından mesele Sarayın kasapbaşına (ser kassâb-ı hassâ) havale ediliyor, koyunlar onun vasitasıyla temin ediliyordu. Son olarak da tedarik edilen kurbanlıklar "koyun kalemine" kaydediliyordu.

Cirit oynanan mekânlara da kısaca temas etmek gerekirse, ilk olarak padişahların bu oyunu tertip etmek için çok özel mekânlara ihtiyaç duymadıklarını söylemek gerekiyor. Mesela ordu hareket halinde yahut seferde bulunduğu zamanlarda ordugâhlarda dahi cirit oynatıldığından yukarıda sıklıkla bahsedilmişti. Burada birkaç örnekle meseleyi pekiştirmek gerekirse III. Mehmed ve 1595 Eğri Seferi'ni vitrine alabiliriz. Bizzat cirit oynadığına ilişkin bir tespitte bulunabilme imkânı sunan kaynaklardan yoksun olduğumuzun unutulmaması koşuluyla III. Mehmed'in söz konusu sefer sırasında ordunun konakladığı menzil noktalarında, hatta Eğri'nin kuşatılmasına ramak kalmışken askerler arasında cirit müsabakaları düzenlettirdiği ve o müsabakaları da zevkle seyrettiği Topçular Kâtibi Abdülkâdîr Efendi (2003: s.134, 146) sayesinde bugüne ulaşan bilgilerdendir.

Ordugâhtan başka kaleler de cirit oynanan mekânlardan birisi olmuştur. Padişahların saraylarına uzak olmaları nedeniyle bizzat onlar tarafından buralarda cirit oynatıldığına ilişkin verilerden yoksun olduğumuzu hatırlatmak suretiyle ilgili yöneticilerce (muhafizlar-eyalet paşaları veya sancakbeyleri) kale surlarında cirit sporu icra ettirildiğini Evliyâ Çelebi nakletmiştir. Ama Evliyâ’nın cirit oynandığını değil, surların ne kadar geniş olduğunu vurgulamak amacıyla söz konusu nakil işlemini gerçekleştirmiş olduğu da unutulmamalıdır.

\footnotetext{
$\dagger$ BOA, C.SM. 134/6726, (5 Zilhicce 1135 / 6 Eylül 1723)

$\$$ BOA, C.SM. 145/7286, (29 Ramazan $1167 / 20$ Temmuz 1754)

$\S \S$ BOA, C.SM. 12/636, (21 Ramazan 1183 / 18 Ocak 1770); BOA, C.SM. 103/5175, (18 Ramazan 1187 / 3 Aralık 1773).

${ }^{* * * *}$ BOA, C.SM. 166/8315, (8 Ramazan 1190 / 21 Ekim 1776); BOA, AE.SABH.I. 149/10077, (21 Ramazan 1193 / 2 Ekim 1779); BOA, C.SM. 163/8152, (17 Cemaziyelevvel 1195 / 11 Mayıs 1781); BOA, C.SM. 149/7451, (18 Ramazan 1195 / 7 Eylül 1781); BOA, C.SM. 166/8322, (19 Ramazan 1199 / 26 Temmuz 1785); BOA, C.SM. 130/6550, (13 Ramazan 1201 / 29 Haziran 1787).

柿 BOA, C.SM. 54/2712, (16 Ramazan 1206 / 8 Mayıs 1792); BOA, C.SM. 9/461, (27 Zilkade 1206/ 17 Temmuz 1792); BOA, C.SM. 11/573, (12 Ramazan 1207 / 23 Nisan 1793); BOA, C.SM. 112/5633, (29 Ramazan 1211 / 28 Mart 1797); BOA, C.SM. 18/907, (26 Zilkade 1213 / 1 Mayıs 1799); BOA, C.SM. 90/4522, (17 Cemaziyelahir 1215 / 5 Kasım 1800); BOA, C.SM. 45/2258, (27 Zilkade 1215 / 11 Nisan 1801); BOA, C.SM. 63/3184, (21 Ramazan 1218 / 4 Ocak 1804); BOA, C.MF. 138/6888, (10 Zilkade 1218 / 21 Şubat 1804); BOA, C.SM. 179/8955, (23 Ramazan 1220 / 15 Aralık 1805); BOA, C.SM. 18/924, (17 Ramazan 1222 / 18 Kasim 1807).
} 
Özellikle Van, Erciş, Budin, Zigetvar, Temeşvar ve İstolni-Belgrad gibi kalelerin surlarının genişliğinin resmedilmesinde seyyahımızın cirit örneğine sıklıkla müracaat ettiği görülmektedir (Evliyâ Çelebi, 2001a; Evliyâ Çelebi, 2001b; Evliyâ Çelebi 2002; Evliyâ Çelebi 2003).

Biraz evvel Avusturya elçisinin onuruna cirit oynanmasına müsaade buyurduğundan bahsedilen III. Ahmed'in, damadı Nevşehirli İbrahim Paşa'nın organizatörlüğünü üstlendiği cirit müsabakalarını hemen her yıl düzenli olarak Sadabâd Kasrı'ndan takip etmiş olduğuna devrin vakanüvisi şahittir (Raşid Mehmed Efendi, 2013). Aynı şekilde Sultan III. Selim'in cirit müsabakalarını ismi ile müsemma bir şekilde Cirit Kasrı'ndan izlediği de tespit edilmiştir (Bilgicioğlu, 2006). Sultan Mahmud'un elçilerin oturdukları bir mevkide 1812 yılında bir cirit müsabakası düzenlettiği, hatta bu oyuna bizzat katıldığı bilinmektedir (Güven, 1999). Sultan Mahmud sadece cirit sporunu icra ederken değil, aynı zamanda mahir olduğu bir diğer spor olan okçulukta da benzer eylemler içerisinde bulunmuştur (Uyanık-Boran-Güven, 2017).

Seferlerin oluşturduğu kaotik ortam içerisinde dahi padişahların ciritle ilgili düzenlemeler yapmaktan geri durmamış olmalarına ilişkin kayıtlar konuya atfedilen önemi apaçık ortaya koymaktadır. Mesela Osmanlı ile Rusya ve Avusturya arasında cereyan eden 1787-1792 savaşlarının sürdüğü 1789 senesinde I. Abdülhamid yayınlamış olduğu bir hatt-1 hümâyûnunda ordunun cepheye uğurlanmasının hemen ardından cirit atiyyesine bir nizam verileceğinden ve mevzubahis cirit müsabakasının (temaşasının) masraflarının karşılanacağından bahsediyordu (BOA, AE.SABH.I. 3/295, 10 Receb 1203 / 6 Nisan 1789).

\section{Sonuç}

Günümüzde, kültürel ve sportif sahanın neredeyse tamamında önemini yitirmiş olan ata sporu atlı ciridin Osmanlılar zamanında oldukça popüler bir şekilde yaygınlık kazandığını vurgulamak yanlış olmayacaktır. Atlı cirit önceki Türk devletlerinde olduğu gibi Osmanlılar devrinde de sadece seyir zevki sunan sportif bir faaliyet değil, ordu ekseninde bir savaşa hazırlık felsefesi, ordu mensupları açısındansa iyi ata binme becerisi yanında çeviklik ve cesaret kazanmanın yegâne vasıtalarından biri olarak telakki edilmiştir. Arz ettiği çok görkemli, hareketli, hatta tehlikeli addedilebilecek oyun yapısıyla atlı cirit yabancı elçilere bir "gözdăğı" verme, ayrıca imparatorluğun ihtişamını yansıtma yollarından birisi olmuştur.

Osmanlı padişahlarından bazıları bir yandan cirit binerek bu oyun sahasında boy göstermişken, büyük bir kısmı da çeşitli mekânlarda cirit müsabakaları organize ettirerek ve organizasyonun ardından katılımcılara çeşitli ödüller dağıtarak hem oyunun devamına hem de oyuncuların devamlılığına katkıda bulunmayı ihmal etmemişlerdir. Osmanlı arşivlerinin önemli mensuplarından olan "Ceyb-i Hümâyûn Defterleri" bu hususta tarafsız bir tanıklıkta bulunmaya fazlasıyla hazır olduklarını biz araştırmacılara göstermişlerdir. İleride söz konusu defterler başta olmak üzere diğer arşiv kayıtlarından ve çağdaş eserlerden hareketle ortaya konulacak daha mufassal çalışmalar Osmanlı sultanları ve atlı cirit oyunu arasındaki ilişkiye dair bilinenlerin artmasına katkı sağlayacaktır. $O$ sayede bugün neredeyse unutulmaya yüz tutmuş olan bu ata sporu Türk toplumu ile Türklerin spor ve kültür vitrininde ziyadesiyle hak ettiğini düşündüğümüz eski yerine kavuşacaktır kanaatindeyiz. 
Yüksel, A., Gül, M., ve Güven, O. (2018). Padişah cirit bindi! (Cirit sporunu icrâ eden ve destekleyen Osmanlı Sultanları). Spor Bilimleri Araştırmaları Dergisi, 3(1), 145-163.

\section{KAYNAKLAR}

\section{Başbakanlık Osmanlı Arşivi (BOA)*}

Topkapı Sarayı Müzesi Arşivi Defterleri (TSMA.d.): 2351; 2368; 2432; 2434/116; 2434/11.

Ali Emirî Sultan Abdülhamid I. (AE.SABH.I.): 3/295; 149/10077.

Ali Emirî Sultan Ahmed III (AE. SAMD.III.): 215/20805; 227/21846.

Cevdet Saray (C.SM.): 64/3222; 49/2462; 134/6726; 145/7286; 134/6726; 145/7286; 12/636; 103/5175; 166/8315; $163 / 8152 ; 149 / 7451 ; 166 / 8322 ; 130 / 6550 ; 54 / 2712 ; 9 / 461 ; 11 / 573 ; 112 / 5633 ; 18 / 907 ; 90 / 4522 ; 45 / 2258$; 63/3184; 138/6888; 179/8955; 18/924.

Hatt-1 Hümâyûn: 188/8971; 238/13239; 1443/59277.

\section{Basılı Kaynaklar ve Araştırma-İnceleme Eserler}

Ağa, H. H. İ. (1987). Tarih-i Enderun / Letaif-i Enderun (1812-1830), (Çev. Cahit Kayra). İstanbul: Güneş Yayınlar1.

Ahıskalı, R. (2007). Rami Mehmed Paşa. İstanbul: DİA.

Akgündüz, A., ve Öztürk, S. (1999). 700. Yılında Bilinmeyen Osmanlı. İstanbul: OSAV.

Anonim Osmanlı Tarihi, (2000). Anonim Osmanlı Tarihi (1099-1116/1688-1704). (Haz. Abdülkadir Özcan), Ankara.

Ata Sporu Cirit. (1974). Ata Sporu Cirit. Ankara: Erzurum Atlı Spor Kulübü Yayını.

Baykara, T. (2005). Türk Kültürü. İstanbul: IQ Kültür Sanat Yayıncılık.

Baykara, T. (2009a). Türk İkılap Tarihi ve Atatürk İlkeleri. İstanbul: IQ Kültür Sanat Yayınc1lık.

Baykara, T. (2009b). Türk Kültür Tarihine Bakışlar. İstanbul: IQ Kültür Sanat Yayıncılı.

Baykara, T. (2009c). Türk-Türklük ve Türkler. İstanbul: IQ Kültür Sanat Yayıncılık.

Bilgicioğlu, B. (2006). Sarây-ı Âtik-i Âmire XXXVI. İstanbul: DİA.

Bozkurt, S. (2010). Kayseri Yöresinde At Kültürü. Yayınlanmamış Yüksek Lisans Tezi, Erciyes Üniversitesi, Sosyal Bilimler Enstitüsü, Kayseri.

Cezar, M. (1959). Mufassal Osmanlı Tarihi. İstanbul: Türk Tarih Kurumu Yayınları.

Çınar, A. A. (1995). Türklerde At ve Atçılık. Ankara: Kültür Bakanlığı Yayınları.

Çiftçi, S. (2011). Uşak’ta Atlı Cirit Sporu ve Cirit Kültürü. Millî Folklor, 23(89), 99.

Danişmend, İ. H. (1972). İzahlı Osmanlı Kronolojisi. İstanbul: Türkiye yayınevi.

Dingeç, E. (2011). Osmanlı Sarayı'nda Cirit Alayları: Lahanacılar ve Bamyacılar. Millı̂ Folklor, 23(89), 78.

Emiroğlu, K., ve Yüksel, A. (2009). Yoldaşımız At. İstanbul: Yapı Kredi Yayınları.

Evliya Çelebi. (1996). Evliyâ Çelebi Seyahâtnâmesi. C. I, (Haz. Orhan Şaik Gökyay). İstanbul: Yapı Kredi Yayınları.

\footnotetext{
*Vesikalar "Fon adı, defter-gömlek no" şeklinde belirtilmiştir. "BOA, Fon adı, defter gömlek-no, hicrî / miladî tarihli" şeklinde tam künyeleri metin içerisinde yer almaktadır.
} 
Yüksel, A., Gül, M., ve Güven, O. (2018). Padişah cirit bindi! (Cirit sporunu icrâ eden ve destekleyen Osmanlı Sultanları). Spor Bilimleri Araştırmaları Dergisi, 3(1), 145-163.

Evliya Çelebi. (2001b). Evliyâ Çelebi Seyahâtnâmesi. C. IV, (Haz. Yücel Dağl1, Seyit Ali Kahraman). İstanbul: Yap1 Kredi Yayınları.

Evliya Çelebi. (1999a). Evliyâ Çelebi Seyahâtnâmesi. C. II, (Haz. Zekeriya Kurşun, Seyit Ali Kahraman, Yücel Dağl1). İstanbul: Yap1 Kredi Yayınları.

Evliya Çelebi. (1999b). Evliyâ Çelebi Seyahâtnâmesi. C. III, (Haz. Seyit Ali Kahraman, Yücel Dağl1). İstanbul: Yap1 Kredi Yayınları.

Evliya Çelebi. (2001a). Evliyâ Çelebi Seyahâtnâmesi. C. V, (Haz.Yücel Dağl1, Seyit Ali Kahraman, İbrahim Sezgin). İstanbul: Yapı Kredi Yayınları.

Evliya Çelebi. (2002). Evliyâ Çelebi Seyahâtnâmesi. C. VI, (Haz. Seyit Ali Kahraman, Yücel Dağlı). İstanbul: Yap1 Kredi Yayınları.

Evliya Çelebi. (2003). Evliyâ Çelebi Seyahatnamesi. C. VII, (Haz. Yücel Dağlı, Seyit Ali Kahraman, Robert Dankoff). İstanbul: Yapı Kredi Yayınları.

Gelibolulu, M. A. (2004). Künhü’l-Ahbar. (c: II. Fatih Sultan Mehmet Devri)(Haz: M. Hüdâi Şentürk), TTK, Ankara: Türk Tarih Kurumu Yayınları.

Gezder, N. (1998). Geleneksel sporlarımızdan atasporu-Cirit. Erzurum: Eser Ofset.

Gülensoy, T. (2011). Barbar Türkler. Ankara: Akçağ Yayınları.

Güven, Ö. (1999). Türklerde Spor Kültürü. Ankara: Türk Tarih Kurumu Basımevi.

Halıc1, F. (1993). Cirit. İstanbul: DİA.

Hasan Beyzâde, A. P. (2004). Hasan Beyzâde Târîhi. C. III, (Haz. Şevket Nezihi Aykut). Ankara.

Hezarfen, Hüseyin Efendi. (1998). Telhisü'l-Beyân Fî Kavânîn-i Âl-i Osmân. (Haz. Sevim İlgürel). Ankara.

İlgürel, M. (1988). Abaza Paşa. İstanbul: DİA.

İlgürel, M. (1989). Ahmed I. İstanbul: DİA.

Kafesoğlu, İ. (2010). Türk Milli Kültürü. İstanbul: Ötüken Yayınları.

Kahraman, A. (1995). Osmanlı Devleti’nde Spor. Ankara: Kültür Bakanlığg.

Karal, E. Z. (1942). Selim III'ün Hatt-ı Hümayunları. Ankara: Türk Tarih Kurumu.

Katip Çelebi, (2016). Fezleke. (Haz. Zeynep Aycibin). İstanbul: Kültür Bakanlığı.

Kolçak, Ö. (2012). Habsburg Elçisi Walter Leslie'nin Osmanlı Devlet Yapısına Dair Gözlemleri (1665). Tarih Dergisi, 54(1), 55-89.

Küçük, C. (1988). Abdülaziz, İstanbul: DİA.

Lamartine, A. (2008). Osmanlı Imparatorluğu Tarihi, (Çev. Serhat Bayram), İstanbul: Kapı Yayınları.

Mehmet Halife, (1976). Tarih-i Gılmani, (Haz. Kamil Su), İstanbul.

Merçil, E. (2011). Müslüman Türk Devletleri Tarihi. Ankara: Bilge Kültür Sanat.

Naima Mustafa Efendi, (1968). Naima Tarihi. (Çev. Zuhuri Danışman). İstanbul: Nigar Sahaf.

Ögel, B. (1985). Türk kültür tarihine giriş. C. I-II-III-IV-V-VI-VII-VIII). Ankara: Kültür ve Turizm Bakanlığ1 
Yüksel, A., Gül, M., ve Güven, O. (2018). Padişah cirit bindi! (Cirit sporunu icrâ eden ve destekleyen Osmanlı Sultanları). Spor Bilimleri Araştırmaları Dergisi, 3(1), 145-163.

Öngel, H. B. (2001). Türk kültür tarihinde spor. Ankara: Kültür Bakanlığı Yayınları.

Öz, M. (2002). II. Viyana seferi’ne kadar XVII. yüzyıl Türkler. C. IX, (Ed. Kemal Çiçek, Salim Koca, Hasan Celal Güzel), Ankara.

Özcan, A. (2003a). Mehmed IV. C. XXVIII. İstanbul: DİA.

Özcan, A. (2003b). Mahmud I. C. XXVII. İstanbul: DİA.

Özcan, A. (2006). Mustafa II. C. XXXI. İstanbul: DİA.

Derin, F. Ç. (2008). Abdurrahman Abdi Paşa vekâyi'-nâmesi: Osmanlı tarihi (1648-1682) (Vol. 67). İstanbul: Çamlica.

Râşid Mehmed Efendi. (2013). Târîh-i Râşid ve Zeyli. C. II, (Haz. Abdülkadir Özcan, Yunus Uğur vd.) İstanbul: Klasik Kitaplar Yayınevi.

Sümer, F. (1983). Türklerde Atçılık ve Binicilik. İstanbul: Türk Dünyası Araştırmaları Vakfı.

Topçular Kâtibi Abdülkâdîr Efendi. (2003). Topçular Kâtibi Târîhi. (Haz. Ziya Yılmazer). Ankara: Türk Tarih Kurumu Yayınları.

Uslu, Y. B. (2011). Kanunî tek okla üç domuz vurmuştu. Atlas Tarih, 7(1), 36-37.

Uyanık, M., Boran, M., ve Güven, O. (2017). Gelenekten geleceğe Türk okçuluğu hikayeleri. İzmir: Karesi Belediyesi Yayınları.

Yıldırım, Y., İmamoğlu, O., ve Türkmen, M. (2002). Osmanlı devletinde sporun surnamelere yansıması. Güneyde Kültür Dergisi, 13(136), 1-12.

Yıldız, D. (2002). Çă̆larboyu Türklerde Spor. İstanbul: Telebasım Yayıncılık.

Zinkeisen, J. W. (2011). Osmanlı imparatorluğu Tarihi. (Çev. Nilüfer Epçeli), İstanbul: Yeditepe Yayınevi.

Zorba, H. A. (2014). Evliya Çelebi seyahatnâmesi'ne göre Osmanlı İmparatorluğu'nda spor. International Journal of Science Culture and Sport (IntJSCS), 2(5), 721-732. 


\section{EKLER}

Ek-1: Cirit oynayanlara ve oyunlar esnasinda yaralananlara Padişah ihsanı verilmesi hakkında vesika suretleri

BOA, TSMA.d.2351.

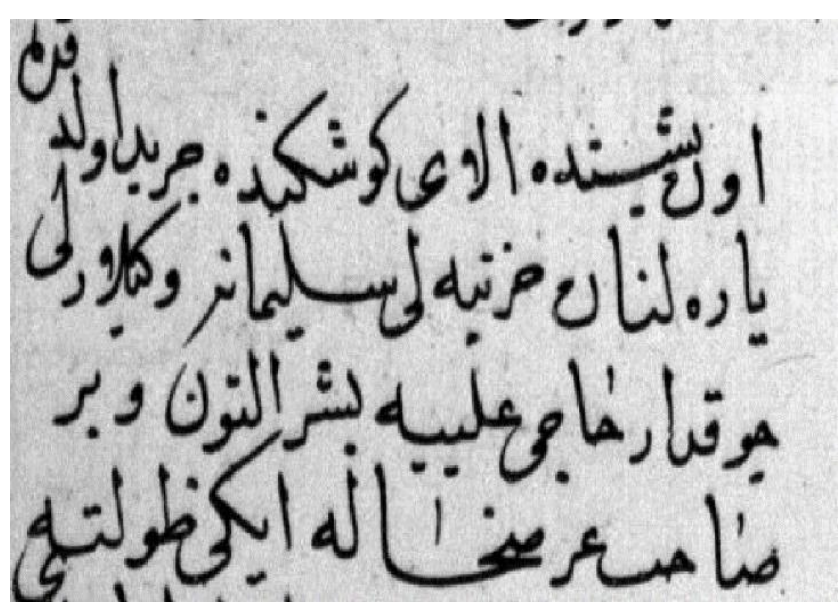

BOA, TSMA.d.2368.

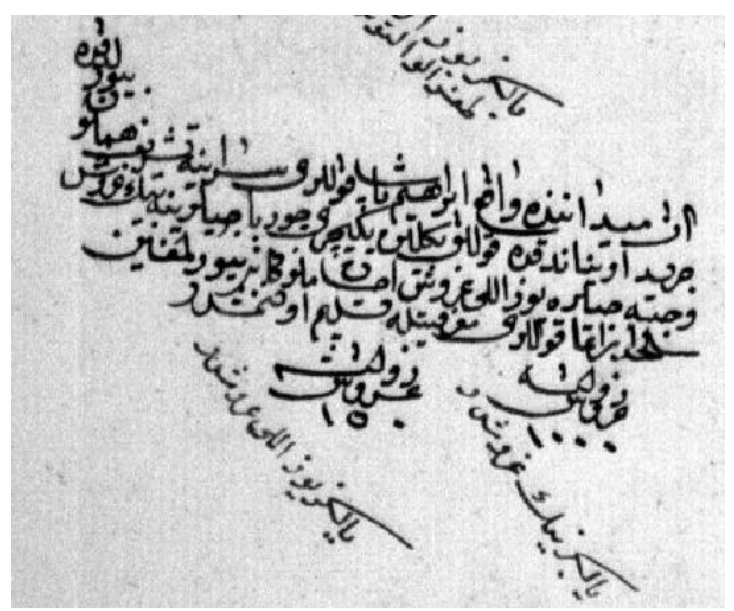

BOA, TSMA.d.2432.

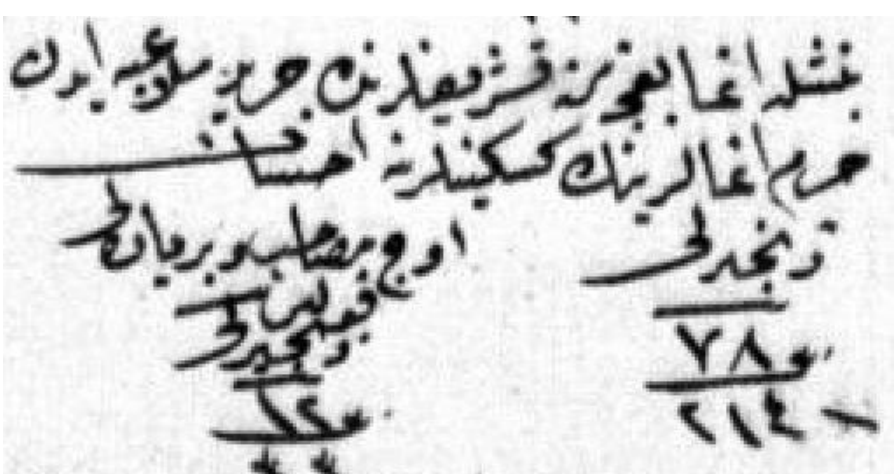

BOA, TSMA.d.2434/116.

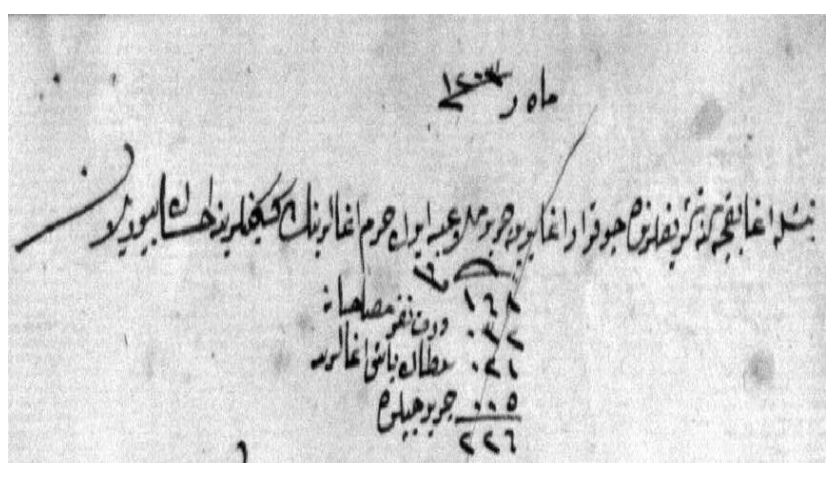


Ek-2: Cirit müsabakası sonrasında ihsana mazhar olan Yeniçeri ve Cebecilere verilen bahşişin kaydının yer aldığı Ceyb-i Hümâyûn Defteri'nin bir parçası(BOA, TSMA.d. 2368).

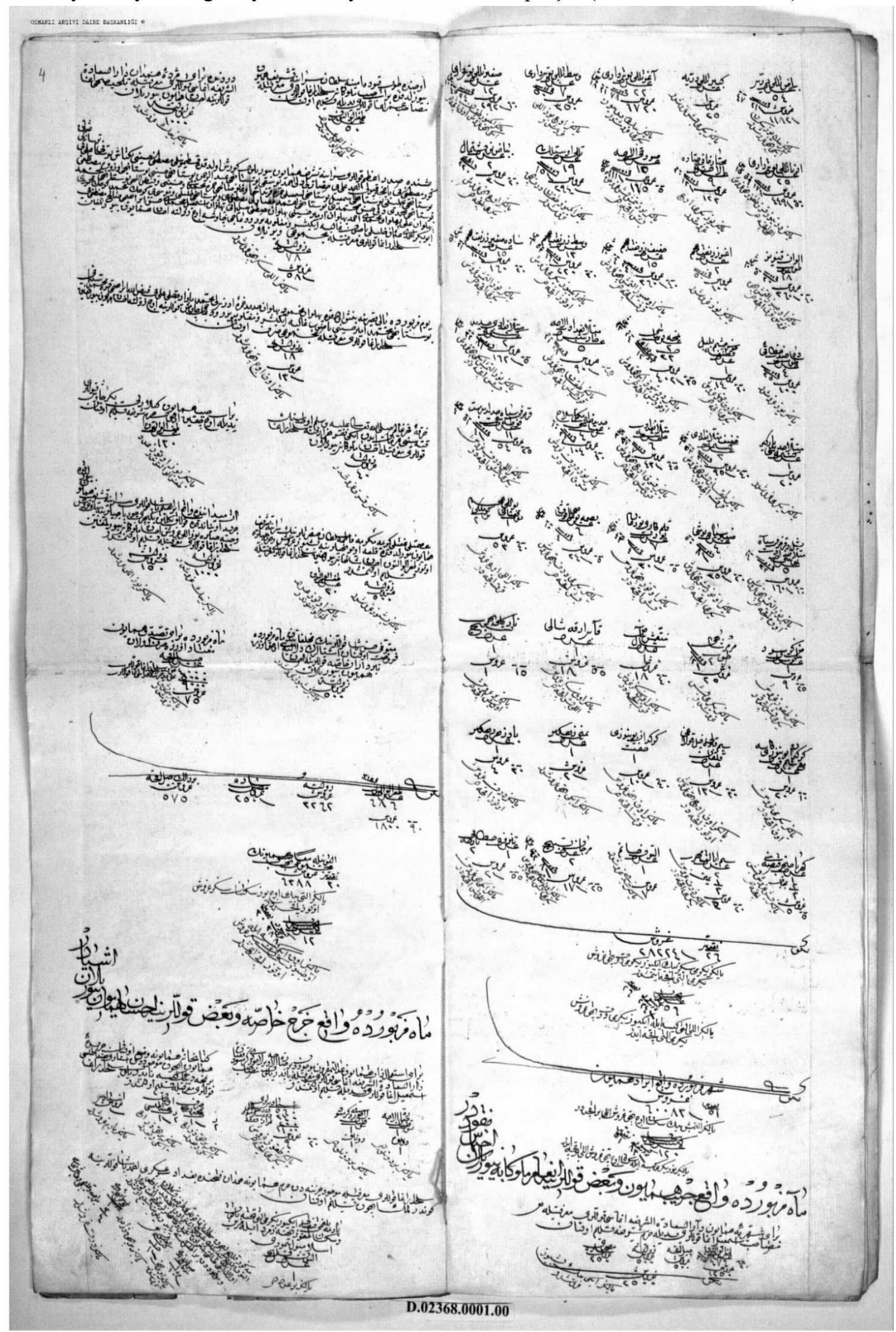

